\title{
High Glucose-Mediated Cytokine Regulation in Gingival Fibroblasts and THP-1 Macrophage: a Possible Mechanism of Severe Periodontitis with Diabetes
}

\author{
Jung-Hwan Lew Koji Naruishi Yukari Kajiura Yasufumi Nishikawa \\ Takahisa Ikuta Jun-ichi Kido Toshihiko Nagata \\ Department of Periodontology and Endodontology, Tokushima University Graduate School of \\ Biomedical Sciences, Tokushima, Japan
}

\section{Key Words}

Diabetes $•$ Fibroblasts $・ I L-1 \beta \cdot$ Macrophages $\cdot$ Periodontitis $\cdot$ SIL-6R

\begin{abstract}
Background/Aims: Diabetic patients are susceptible to severe periodontitis, but the precise mechanism is not fully understood. Aim of this study was to explore the biological pathogenesis of severe periodontitis in diabetic patients focusing on the crosstalk of human gingival fibroblasts (HGFs) and macrophages. Methods: A total of 70 periodontitis patients with or without diabetes mellitus (DM) were enrolled, and the statistical relationships of diabetic conditions to the periodontal inflammatory parameters were examined by cross-sectional study. In in vitro study, HGFs cell line CRL-2014 ${ }^{\circledR}$ (ATCC) and differentiated THP-1 macrophages were cultured with normal glucose (NG: $5.5 \mathrm{mM}$ ) or high glucose (HG: $25 \mathrm{mM}$ ) condition, and treated with indicated inflammatory factors such as calprotectin (CPT), interleukin (IL)- $1 \beta$ and IL-6. To examine the effects of HG on soluble IL-6 receptor (sIL-6R) production in THP1 macrophages, the supernatants were collected and the sIL-6R levels were measured by ELISA. To examine the effects of HG on IL- $1 \beta$ or IL- 6 -induced matrix metalloproteinase (MMPs) production in HGFs, the supernatants were collected. Levels of MMP-1 and tissue inhibitor of MMP-1 (TIMP-1) were measured by ELISA. Finally, after conditioned medium (CM) from THP-1 macrophages cultured with NG or HG conditions was collected, HGFs were treated with the $\mathrm{CM}$. The supernatants were collected 24 hours later and the levels of MMP- 1 and TIMP- 1 were measured. To examine the specific effects of IL-1 $\beta$ contained in CM on MMP-1 and TIMP-1 production in HGFs, IL-1 receptor antagonist (IL-1ra) was used. Results: There were statistical correlation between IL-1 $\beta$ and sIL-6R levels in gingival crevicular fluid (GCF) and $\mathrm{HbA} 1 \mathrm{c}$ in periodontitis patients with $D M(I L-1 \beta$ : $P=0.035$, slL-6R: $P=0.040)$. HG and CPT significantly induced sIL-6R production in THP-1 macrophages. HG significantly enhanced IL- $1 \beta$ or IL-6/sIL$6 R$-induced MMP-1 production in HGFs. The increase of MMP- 1 by both IL- $1 \beta$ and IL-6/sIL-6R
\end{abstract}




\section{Cellular Physiology Cell Physiol Biochem 2018;50:973-986 \begin{tabular}{l|l} 
DOI: 10.1159/000494481 & $\begin{array}{l}\text { O 2018 The Author(s). Published by S. Karger AG, Basel } \\
\text { www.karger.com/cpb }\end{array}$
\end{tabular} \\ Lew et al.: High Glucose Induces Severe Periodontitis.}

was significantly inhibited by specific ERK or IKB inhibitors. Corresponding to the regulation of MMP-1 production, HG condition increased the phosphorylation of p44/42 MAPK and IKB $\alpha$ in HGFs treated with IL-1 $1 \beta$ or IL-6/sIL-6R. Finally, MMP-1 production in HGFs cultured with HG increased significantly by CM from THP-1 macrophages cultured with HG. The induction of MMP-1 by the CM from THP-1 macrophages cultured with HG was significantly inhibited by dose dependent of IL-1ra in HGFs cultured with HG. Conclusion: Diabetic conditions such as $H G$ induce IL-1 $\beta$ and sIL-6R production from macrophages in inflammatory periodontal tissues and may exacerbate the periodontitis synergistically via MMP-1 production from HGFs.

(C) 2018 The Author(s)

Published by S. Karger AG, Basel

\section{Introduction}

Diabetes mellitus (DM) is a systemic disease with several complications such as retinopathy, nephropathy and neuropathy [1]. Inflammatory periodontal disease, so-called periodontitis is also one of the diabetic complications [2]. Progression of periodontitis has been associated with poor glucose control in diabetic patients [3], although the precise mechanism remains unknown.

Interleukin (IL)-1 $\beta$ and IL-6 are considered to be important pro-inflammatory cytokines that elicit a wide variety of biologic activities [4], and induce the progression of periodontitis [5]. A soluble form of interleukin 6 receptor (sIL-6R), known as an IL-6 agonist, is released by proteolytic cleavage from cell surface of immune/inflammatory cells such as lymphocytes and macrophages [6]. Our recent findings showed that sIL-6R levels in gingival crevicular fluid (GCF) of inflamed sites are significantly higher than in the healthy sites in periodontitis patients [7]. Importantly, it has been reported that both IL-1 $\beta$ and IL-6 levels in GCF were significantly elevated in diabetic patients $[8,9]$. Although synergistic effects of these cytokines may induce the severe periodontitis in diabetic patients, the relationship of diabetic conditions such as high glucose (HG) to the cytokine cascades are not fully understood.

Human gingival fibroblasts (HGFs) are the most abundant cells in periodontal connective tissues [10]. HGFs can be target of IL-6 in the presence of sIL-6R, even though HGFs do not express sufficient cell-surface IL-6R to bind appreciable levels of IL-6 [11]. Therefore, sIL$6 \mathrm{R}$ is an essential molecule for IL-6 signaling in HGFs. In addition, significant elevation of calprotectin (CPT), a heterodimer of S100A8 and S100A9, are found in inflamed periodontal tissues [7]. Our previous findings showed that CPT induces not only IL-6 production in HGFs [12], but also sIL-6R production in THP-1 macrophages [7], resulting in progression of periodontitis by induction of IL- 6 cascades. Furthermore, vascular endotherial growth factor (VEGF) is a significant factor for diabetic complications, and is implicated in the development of neovascularization and endotherial dysfunction in diabetic retinopathy [13]. We showed that HG enhances IL-6/sIL-6R-induced VEGF production in HGFs [14]. A series of reports suggest that exaggerated response of HGF affected by both elevated glucose and inflammatory cytokines may lead to severe periodontitis.

Matrix metalloproteinases (MMPs) are important enzymes responsible for degradation of extracellular matrix (ECM) such as collagen [10]. Periodontal tissue destruction often correlates with an imbalance between MMPs and their inhibitors of MMPs (TIMPs) [15]. HGFs have important roles in gingival healing by regulating production of MMPs/TIMPs in periodontitis lesions [16]. Although there is a positive relationship between uncontrolled DM and severe periodontitis, the effects of HG on the production of MMPs/TIMPs in HGFs are unclear.

In the present study, we examined whether inflammatory cytokines in GCF have been associated with clinical parameters in diabetic patients by performing clinical cross-sectional study. Furthermore, we examined the effects of HG conditions on crosstalk between HGFs and macrophages in order to clarify the pathogenesis of severe periodontitis in diabetic patients in the viewpoint of IL-6 trans-signaling. 


\section{Cellular Physiology Cell Physiol Biochem 2018;50:973-986 \begin{tabular}{ll|l} 
and Biochemistry 10.1159/000494481 & $\begin{array}{l}\text { O 2018 The Author(s). Published by S. Karger AG, Basel } \\
\text { Publisned online: } 23 \text { October } 2018 \text { warger.com/cpb }\end{array}$ \\
\cline { 2 - 3 }
\end{tabular} \\ Lew et al.: High Glucose Induces Severe Periodontitis.}

\section{Materials and Methods}

\section{Subjects and oral/diabetic examination}

A total of 70 patients with chronic periodontitis (35 males, 35 females, average age, $64.1 \pm 7.8$ yr), who visited the outpatient clinic of Department of Periodontics, Tokushima University Hospital between 2015 and 2017 were enrolled in this study. Chronic periodontitis was diagnosed based on the criteria set forth by the American Academy of Periodontology [17]. Oral conditions such as number of teeth, bleeding on probing (BOP) and periodontal pocket depth (PPD) were evaluated by trained dentists, and all examiners used the same evaluation standards to reduce inter-examiner error. Patients with or without DM were recorded by a directed interview. The blood samples were collected, and casual blood sugar level (BS) and hemoglobin A1c (HbA1c) were measured immediately using checkart reader (Shionogi CO., LTD., Osaka, Japan). In order to estimate the levels of advanced glycation end-products (AGEs) accumulation in the skin, the skin autofluorescence (AF) was measured using AGE Reader (Neuroscience, Inc., Tokyo, Japan). The criteria for exclusion in this study is as follows: 1. Patients with pregnant women or in lactation. 2. Patients with systemic antibiotic intake or frequent use of anti-inflammatory drugs.

The study protocol was approved by the local ethics committee of Tokushima University Hospital (No. 2325) and the study was conducted in accordance with the principles of the Helsinki Declaration. All participants provided written informed consent.

GCF sampling and measurement of GCF sIL-6R/calprotectin levels

GCF samples were collected from 1 deepest periodontal pocket by inserting sterile 2 paper points (absorbent paper points \#45, Dentsply/Maillefer, Ballaigues, Switzerland) in each patient as described in previous report [7]. IL-1 $\beta$, sIL-6R and CPT levels in GCFs were measured using ELISA Kits (IL-1 $\beta$, sIL-6R: R\&D Systems, Minneapolis, MN; CPT: Hycult Biotech, PB Uden, Netherlands).

\section{Reagents}

Recombinant human (rh) CPT, rhIL-6, rhsIL-6R, rhIL-1 $\beta$ and rhIL-1 receptor antagonist (IL-1ra) were obtained from R\&D Systems. Phorbol 12-myristate 13-acetate (PMA) and antibody to $\beta$-actin were obtained from Sigma (St. Louis, MO). Porphyromonas gingivalis (Pg) LPS was purchased from Invitrogen (Carlsbad, CA, USA). TAPI-1, inhibitor of TNF- $\alpha$-converting enzyme (TACE), was purchased from Calbiochem (Darmstadt, Germany). Antibodies to phospho-p44/42 MAPK and phospho-IкB $\alpha$ were obtained from Cell Signaling (Beverly, MA). Mannitol was purchased from Nakarai Tesque (Kyoto, Japan).

\section{Cell culture}

The human monocytic leukemia cell line THP-1 cells (ATCC) were maintained in RPMI 1640 (GIBCOBRL, Rockville, MD) supplemented with $10 \%$ heat-inactivated FBS and antibiotics (Invitrogen). THP-1 cells were differentiated by $100 \mathrm{nM}$ PMA, and the differentiated THP-1 cells were cultured in normal glucose (NG: $5.5 \mathrm{mM}$ ) or HG (25 mM glucose) condition. As an osmotic control for HG, cells were cultured in NG medium supplemented with mannitol (5.5 mM glucose + $19.5 \mathrm{mM}$ mannitol).

Human gingival fibroblasts cell line CRL-2014® (ATCC) were cultured with DMEM and $10 \%$ FBS. HGFs were also cultured with NG or HG condition, and were treated with indicated stimulations. As an osmotic control for HG, mannitol was also used.

\section{Cell proliferation in THP-1 macrophages}

To examine the effects of HG on cell proliferative activity, MTT assay was performed [12]. In short, differentiated THP-1 macrophages were cultured with NG or HG condition for $24 \mathrm{~h}$ and treated with CPT ( $50 \mathrm{nM}$ ) for $24 \mathrm{~h}$. MTT (final concentration: $0.5 \mathrm{mg} / \mathrm{ml}$ ) was added to each well and incubated for $4 \mathrm{~h}$ prior to the addition of $100 \mu \mathrm{l}$ DMSO. The reaction mixture was measured fluorometrically using auto plate reader (Bio-Rad, Hercules, CA; excitation at $595 \mathrm{~nm}$ ). 


\section{Cellular Physiology Cell Physiol Biochem 2018;50:973-986 \begin{tabular}{ll|l} 
and Biochemistry Published online: 23 October 2018 & $\begin{array}{l}\odot 2018 \text { The Author(s). Published by S. Karger AG, Basel } \\
\text { www.karger.com/cpb }\end{array}$ \\
\hline
\end{tabular} \\ Lew et al.: High Glucose Induces Severe Periodontitis.}

Measurement of inflammation-related proteins secreted by THP-1 macrophages or HGFS

Differentiated THP-1 macrophages of HGFs were treated with indicated conditions. Pg-LPS was used as a positive control for IL-6 production from THP-1 macrophages. Culture supernatants were collected and stocked at $-80{ }^{\circ} \mathrm{C}$. Levels of IL-6, sIL-6R, IL-1 $\beta$, MMP-1, TIMP-1 and VEGF were measured using ELISA kits (R\&D Systems).

\section{Intracellular signaling}

Total cellular proteins were extracted with lysis buffer $(0.5 \%$ SDS, $10 \mathrm{mM}$ Tris- $\mathrm{HCl} \mathrm{pH}$ 7.4, and protease inhibitor mix: Complete ${ }^{\mathrm{TM}}$ [Sigma]) after indicated stimulations. Phosphorylation of p44/42 MAPK and IкB $\alpha$ was examined using Western-blotting according to the previous report [11]. $\beta$-actin was used as internal control of loading proteins.

Conditioned medium (CM) preparation in THP-1 macrophages and effects of CM on MMP-1 production in HGFs

Differentiated THP-1 macrophages were cultured in RPMI 1640 with NG or HG condition for 48 h, and $\mathrm{CM}$ was collected. Collected medium samples were centrifuged at $3000 \mathrm{rpm}$ for $10 \mathrm{~min}$ to remove cell debris, and filtered through a $0.45-\mu \mathrm{m}$ filter. All CM was kept at $-80^{\circ} \mathrm{C}$, and CM diluted $20 \%$ with DMEM was used for stimulations. Levels of MMP-1 and TIMP-1 were measured using ELISA kits (R\&D Systems). To examine the effects of IL-1 $\beta$ contained in CM on the MMP-1 and TIMP-1 production in HGFs, rhIL-1ra (50, $500 \mathrm{ng} / \mathrm{ml}$ ) was used.

\section{Statistical analysis}

Statistical significances were determined by Mann-Whitney U test and pearson's correlation coefficient test for cross-sectional clinical study, since the clinical data were not normally distributed. Next, statistical significances were determined by Student's $t$-test or ANOVA Tukey-HSD analysis for in vitro study. Statistical analyses were performed using JMP ${ }^{\circledR} 8$ ver. 8.0.2 (SAS Institute Japan, Tokyo). P-values of $<0.05$ were considered statistically significant.

\section{Results}

A cross-sectional analysis of several parameters in patients with or without DM

As shown in Table 1 , both levels of $B S$ and HbA1c of patients with DM were significantly higher than in patients without DM (BS, P=0.0008; HbA1c, $\mathrm{P}<0.0001, \quad$ Mann-Whitney $\mathrm{U}$ test). On the other hand, there was no significant difference between periodontitis patients with and without DM in the skin AF levels $(\mathrm{P}=0.34)$. In oral conditions, there was no statistical difference between periodontitis patients with and without $\mathrm{DM}$ in the number of teeth $(\mathrm{P}=0.89)$. There were also
Table 1. Comparison of several parameters between groups of periodontitis patients with or without diabetes. A total of 70 periodontitis patients was enrolled and divided into 2 groups: Periodontitis $(\mathrm{N}=37,63.3 \pm 8.4 \mathrm{yr})$ and Periodontitis with diabetes $(\mathrm{N}=33,64.9 \pm 7.2 \mathrm{yr})$ for cross-sectional study. Data were presented average \pm SD. Levels of IL-1 $\beta$, sIL-6R and CPT in gingival crevicular fluid of deepest PPD [Average PPD ( $\mathrm{mm}$ ), group of Periodontitis: 5.5 \pm 1.4 , group of Periodontitis with diabetes: $5.9 \pm 1.6$ ] were measured using ELISA kit. ${ }^{*} \mathrm{P}<0.05$ (chi-square test or Mann-Whitney U test). N, number of subjects; DM, diabetes; PPD, periodontal pocket depth; BOP, bleeding on probing; sIL-6R, soluble form of interleukin-6 receptor; CPT, calprotectin; Skin AF, Skin autofluorescence; BS, casual blood sugar; HbA1c, Hemoglobin A1c

\begin{tabular}{lccc}
\hline Parameters & Periodontitis & Periodontitis with diabetes & P-value \\
\hline number of subjects (M/F) & $37(16 / 21)$ & $33(19 / 14)$ & 0.23 \\
age (yr) & $63.3 \pm 8.4$ & $64.9 \pm 7.2$ & 0.55 \\
Diabetic conditions & & & \\
BS (mg/dL) & $125.9 \pm 26.2$ & $204.0 \pm 104.9$ & $0.0008^{*}$ \\
HbA1c (\%) & $5.7 \pm 0.4$ & $7.6 \pm 1.1$ & $<0.0001^{*}$ \\
Skin AF (AU) & $2.2 \pm 0.5$ & $2.4 \pm 0.9$ & 0.34 \\
Oral conditions & & & \\
number of teeth & $20.5 \pm 6.0$ & $21.1 \pm 5.4$ & 0.89 \\
ratio of 4 mm<PPD (\%) & $36.1 \pm 33.8$ & $46.2 \pm 35.0$ & 0.25 \\
ratio of mobile teeth (\%) & $12.2 \pm 19.9$ & $29.8 \pm 32.3$ & $0.028^{*}$ \\
ratio of BOP positive (\%) & $34.8 \pm 29.4$ & $49.1 \pm 31.4$ & 0.056 \\
number of with/without & $15 / 22$ & $20 / 13$ & 0.094 \\
6mm>PPD & $31.9 \pm 30.2$ & $46.7 \pm 38.1$ & 0.083 \\
GCF IL-1 $(p$ (pg) & $84.0 \pm 47.6$ & $102.0 \pm 63.7$ & 0.36 \\
GCF sIL-6R levels (pg) & $182.7 \pm 124.7$ & $185.6 \pm 141.1$ & 0.83 \\
GCF CPT levels (ng) & & & \\
\hline
\end{tabular}




\section{Cellular Physiology Cell Physiol Biochem 2018;50:973-986 \begin{tabular}{ll|l} 
and BiOChemistry & $\begin{array}{l}\text { DOI: 10.1159/000494481 } \\
\text { Published onlIne: 23 October 2018 }\end{array}$ & $\begin{array}{l}\text { C } 2018 \text { The Author(s). Published by S. Karger AG, Basel } \\
\text { www.karger.com/cpb }\end{array}$ \\
\hline
\end{tabular} \\ Lew et al.: High Glucose Induces Severe Periodontitis.}

no statistical differences in the periodontal conditions: ratio of 4 $\mathrm{mm}<\mathrm{PPD}$, ratio of BOP positive and number of over $6 \mathrm{~mm}$ PPD $(\mathrm{P}=0.25$, $\mathrm{P}=0.056$ and $\mathrm{P}=0.094$, respectively), although the tendency was observed. Ratio of mobile teeth in diabetic patients was higher significantly than those in non-diabetes $(\mathrm{P}=0.028)$. There was no significant difference in both GCF sIL-6R and CPT in the deepest PPD $(\mathrm{P}=0.36$, $\mathrm{P}=0.83$, respectively). Finally, our supplemental data showed that GCF IL-1 $\beta$ and sIL-6R levels in group of periodontitis patients with PPD greater than $6 \mathrm{~mm}$ were higher significantly than in periodontitis patients without PPD greater than $6 \mathrm{~mm}(\mathrm{P}=0.0015, \mathrm{P}=0.042$, respectively), when the population was divided into 2 groups as follow: the groups of patients with or without $6 \mathrm{~mm}$ over PPD (see Supplemental Table 1 - for all supplemental material see www.karger.com/10.1159/000494481/).

Statistical associations between GCF IL-1 $\beta$ and sIL-6R levels and inflammation/diabetesrelated factors

As shown in Table 2, there were no statistical correlation between GCF IL-1 $\beta$ levels and inflammatory/diabetic factors in periodontitis patients (PPD: $\mathrm{P}=0.34$, GCF CPT: $\mathrm{P}=0.19$, BS: $\mathrm{P}=0.65$, HbA1c: $\mathrm{P}=0.56)$. On the other hand, there were statistical correlation between GCF IL-1 $\beta$ levels and inflammatory/diabetic factors in periodontitis patients with DM (PPD: $\mathrm{P}=0.030$, GCF CPT: $\mathrm{P}=0.0001$, HbA1c: $\mathrm{P}=0.035$ ). Levels of GCF sIL-6R correlated statistically to the inflammatory factors in periodontitis patients with or without diabetes (Periodontitis: PPD, $\mathrm{P}=0.0001$, GCF CPT: $\mathrm{P}=0.002$; Periodontitis with $\mathrm{DM}$ : $\mathrm{PPD}, \mathrm{P}=0.006, \mathrm{CPT}, \mathrm{P}=0.019$ ). GCF sIL-6R levels correlated statistically to the values of $\mathrm{HbA1c}$ in periodontitis patients with $\mathrm{DM}$ $(\mathrm{P}=0.040, \mathrm{r}=0.38$, pearson's correlation coefficient test). GCF sIL-6R levels did not correlate to the values of other diabetic factors in periodontitis patients with DM (skin AF: $P=0.28$, BS: $\mathrm{P}=0.29$ ). In the group of periodontitis patients, no significant relationships were observed between GCF sIL-6R levels and DM-related factors (skin AF: $\mathrm{P}=0.40, \mathrm{HbA1c}$ : $\mathrm{P}=0.53$, BS: $\mathrm{P}=0.43)$.

Induction of sIL-6R production in THP-1 macrophages by CPT

Although both CPT and PMA did not induce IL-6 production in THP-1 macrophages, Pg LPS increased significantly the IL-6 production in the cells $(\mathrm{P}<0.0001$, ANOVA-Tukey HSD) (Fig. 1A). As shown in Fig. 1B, both CPT and PMA increased significantly sIL-6R production in THP-1 macrophages, and TAPI-1 suppressed completely the increase of sIL-6R production by CPT (P<0.0001, CPT vs. CPT+TAPI-1, ANOVA-Tukey HSD). Pg LPS did not increase the sIL$6 \mathrm{R}$ production in the cells.

Table 2. Correlation between GCF IL-1 $\beta$ and sIL-6R levels and several clinical parameters. A total of 70 periodontitis patients was enrolled and divided into 2 groups: Periodontitis $64.9 \pm 7.2 \mathrm{yr}$ ) for cross-sectional study. Correlation between GCF IL-1 $\beta$ / sIL-6R levels of deepest PPD and several clinical parameters were analyzed using Pearson's correlation coefficient test. $r$, correlation coefficient. GCF, gingival crevicular fluid; sIL-6R, soluble form of interleukin-6 receptor; PPD, periodontal pocket depth; CPT, calprotectin; skin AF, Skin autofluorescence; BS, casual blood sugar; bA1c, Hemoglobin A1c. *, $\mathrm{P}<0.05$; **P<0.01

\begin{tabular}{lccccc}
\hline \multirow{2}{*}{ Diagnosis } & \multirow{2}{*}{ Parameters } & \multicolumn{2}{c}{ GCF IL-1 $\beta$} & \multicolumn{2}{c}{ GCF sIL-6R } \\
& r & P-value & r & P-value \\
\hline Periodontitis & age & 0.28 & 0.12 & 0.26 & 0.11 \\
& PPD & 0.17 & 0.34 & 0.58 & $0.0001^{* *}$ \\
& GCF CPT levels & 0.24 & 0.19 & 0.50 & $0.002^{* *}$ \\
& BS & 0.09 & 0.65 & 0.14 & 0.43 \\
Periodontitis with DM & HbA1c & 0.11 & 0.56 & 0.11 & 0.53 \\
& Skin AF & 0.01 & 0.98 & 0.15 & 0.40 \\
& age & 0.24 & 0.18 & 0.07 & 0.70 \\
& PPD & 0.38 & $0.030^{*}$ & 0.47 & $0.006^{* *}$ \\
& GCF CPT levels & 0.63 & $0.0001^{* *}$ & 0.41 & $0.019^{*}$ \\
& BS & 0.17 & 0.38 & 0.20 & 0.29 \\
& HbA1c & 0.40 & $0.035^{*}$ & 0.38 & $0.040^{*}$ \\
& Skin AF & 0.22 & 0.30 & 0.23 & 0.28 \\
\hline
\end{tabular}




\section{Cellular Physiology Cell Physiol Biochem 2018;50:973-986 and Biochemistry \begin{tabular}{l|l} 
DOl: 10.1159/000494481 & $\begin{array}{l}\text { O 2018 The Author(s). Published by S. Karger AG, Basel } \\
\text { www.karger.com/cpb }\end{array}$
\end{tabular}

Fig. 1. Effects of calprotectin on IL-6 and sIL-6R production in THP-1 macrophages. Levels of (A) IL-6, (B) sIL$6 \mathrm{R}$ production in THP-1 macrophages. After cells were cultured with $5.5 \mathrm{mM}$ glucose (NG) condition, the cells were treated with CPT (50 nM), PMA (100 $\mathrm{nM})$ and Pg LPS (1 $\mu \mathrm{g} / \mathrm{ml})$ for $24 \mathrm{~h}$ and collected the supernatants. Both IL-6 and sIL-6R levels were measured using ELISA methods. To inhibit the tumor

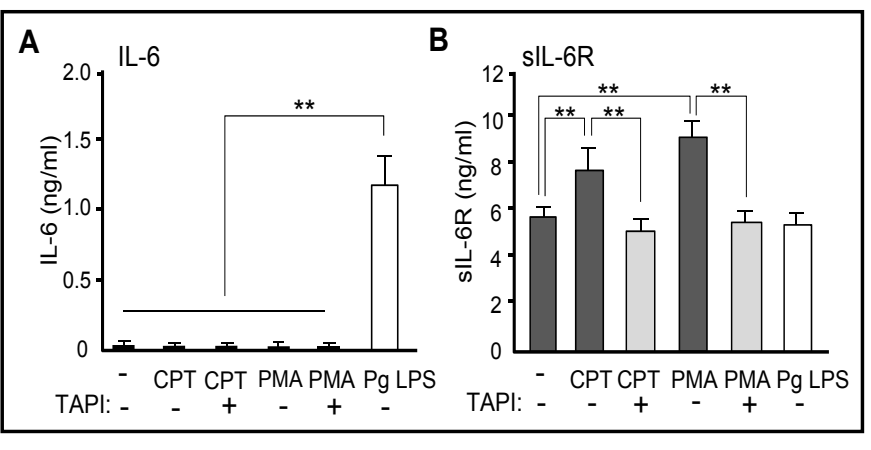
necrosis factor-alpha converting enzyme

(TACE) activity, the cells were pretreated with the inhibitor of TACE (TAPI-1) (10 $\mu \mathrm{M})$. Data represents as the mean \pm SD from 3 independent experiments. ${ }^{* *}, \mathrm{P}<0.01$ as compared with control (ANOVA Tukey-HSD). CPT, calprotectin; PMA, phorbol 12-myristate 13-acetate; Pg LPS, Porphyromonas gingivalis lipopolysaccharide.

Fig. 2. Effects of high glucose on IL-1 $\beta$ and sIL-6R production in THP-1 macrophages. After THP-1 macrophages were cultured with $5.5 \mathrm{mM}$ glucose (NG) or $25 \mathrm{mM}$ glucose (HG) condition, the cells were treated with $50 \mathrm{nM} \mathrm{CPT}$. As an osmotic control for $\mathrm{HG}$, the cells were cultured with NG conditions supplemented with $19.5 \mathrm{mM}$ mannitol (MN). (A) Cell proliferation. Cell proliferative activity was determined by MTT assay. Levels of CPT-induced (B) IL-1 $\beta$, (C) IL-6, (D) sIL-6R production in THP-1 macrophages cultured with NG or HG conditions. After the cells were treated with CPT for $24 \mathrm{~h}$ and collected the supernatants. Both IL-1 $\beta$ and sIL-6R levels were measured using ELISA methods. (E) To inhibit TACE activity, the cells were pretreated with TAPI-1 $(10 \mu \mathrm{M})$ for $24 \mathrm{~h}$. Data represents as the mean \pm SD from 3 independent experiments. CPT, calprotectin. TACE, tumor necrosis factor-alpha converting enzyme. TAPI-1, inhibitor of TACE. NS, not significant differences. *, $\mathrm{P}<0.05 ; * *, \mathrm{P}<0.01$, ANOVA Tukey-HSD.

\section{Effects of HG on cell proliferative activity in THP-1 macrophages}

No significant differences were observed in the cell proliferation between NG and HG in THP-1 macrophages ( $\mathrm{P}=0.74$, ANOVA Tukey-HSD) (Fig. 2A). CPT did not induce the cell proliferative activity (NG vs. NG+CPT: $\mathrm{P}=0.99$, ANOVA Tukey-HSD). The cell morphology did not change throughout the experiments.

\section{Effects of HG on production of inflammatory cytokines in THP-1 macrophages treated with CPT}

HG increased significantly IL-1 $\beta$ and sIL-6R production, but not IL-6 in THP-1 macrophages (IL-1 $\beta$ : P<0.001; sIL-6R: $\mathrm{P}=0.0067$, ANOVA Tukey-HSD) (Fig. 2B-2D). CPT enhanced significantly the levels of HG-induced IL-1 $\beta$ production, but not sIL-6R in the cells (IL-1ß: $\mathrm{P}<0.0001$; sIL-6R: $\mathrm{P}=0.55$, ANOVA Tukey-HSD). As shown in Fig. 2E, significant increase of sIL-6R productions were observed in THP-1 macrophages treated with glucose in a dose dependent manner, and the increase of sIL-6R productions were inhibited significantly by pretreatment of TAPI- $1(\mathrm{P}<0.0001$, Student's $t$-test $)$. 
Fig. 3. Effects of high glucose on IL-1 $\beta$ induced MMP-1 and TIMP-1 production in HGFs. Levels of (A) MMP-1, (B) TIMP1 production in HGFs. After HGFs were cultured with $5.5 \mathrm{mM}$ glucose (NG) or $25 \mathrm{mM}$ glucose conditions, cells were treated with IL-1 $\beta(1 \mathrm{ng} / \mathrm{ml})$ for $24 \mathrm{~h}$ and the culture supernatants were collected. As an osmotic control for HG, the cells were cultured with NG conditions supplemented with $19.5 \mathrm{mM}$ mannitol (MN). (C) For inhibitor experiments, HGFs were pretreated with IKK inhibitor Bay11-7082 (10, 25, $50 \mu \mathrm{M})$ for $8 \mathrm{~h}$, ERK inhibitor U0126 $(10 \mu \mathrm{M})$, or androgen receptor inhibitor flutamide $(10 \mu \mathrm{M})$ for $3 \mathrm{~h}$ and treated with IL-1 $\beta$ for $24 \mathrm{~h}$. MMP1 and TIMP-1 levels were measured using ELISA methods. Data represents as the mean \pm SD from 3 independent experiments. (D) Enhancement of IL$1 \beta$-induced signaling in HGFs cultured with HG conditions. Cell lysates were resolved by SDS-PAGE and analyzed using Western blotting probed with antibodies against phospho-p44/42 MAPK and phospho-IкB $\alpha$. Equal loading of total lysates $(10 \mu \mathrm{g})$ was confirmed by re-probing with antibodies against $\beta$-actin. NS, not significant differences. *,

$\mathrm{P}<0.05$; **, $\mathrm{P}<0.01$, as compared with control (ANOVA Tukey-HSD).

Enhancement of IL-1 $\beta$ or IL-6/sIL-6R-induced MMP-1 production in HGFs cultured with HG conditions

As shown in Fig. 3 and Fig. 4, similar results were observed in both IL-1 $\beta$ and IL-6/sIL6R-induced MMP-1 production in HGFs. IL-1 $\beta$ and IL-6/sIL-6R significantly increased MMP1 production in HGFs, even in NG condition $(\mathrm{P}<0.0001$ vs. untreated cells, ANOVA TukeyHSD). HG enhanced significantly IL-1 $\beta$ - and IL-6/sIL-6R-induced MMP-1 production in HGFs $(\mathrm{P}<0.0001$ vs. NG). HG also increased MMP-1 production, even in HGFs without IL-1 $\beta$ or IL-6/sIL-6R stimulation. Whereas, IL-1 $\beta$ significantly decreased TIMP-1 production in HGFs cultured with both NG and HG condition (NG: $\mathrm{P}=0.0001$; HG: $\mathrm{P}=0.027$, vs. untreated cells, ANOVA Tukey-HSD) (Fig. 3B). Next, both MAPK inhibitor U0126 and NF- $\kappa B$ inhibitor Bay 11-7082 suppressed significantly IL-1 $\beta$-mediated MMP-1 production in HGFs (NG, U0126: $\mathrm{P}<0.0001 ; 10 \mu \mathrm{M}$ Bay: $\mathrm{P}<0.0001 ; \mathrm{HG}, \mathrm{U} 0126: \mathrm{P}<0.0001 ; 10 \mu \mathrm{M}$ Bay: $\mathrm{P}<0.0001$, ANOVA TukeyHSD). Flutamide had no effects on the IL-1 $\beta$-induced MMP-1 production in HGFs cultured with both NG and HG (NG: P=0.99; HG: P=0.76, ANOVA Tukey-HSD). As shown in Fig. 4C, the both inhibitors inhibited significantly IL-6+sIL-6R-mediated MMP-1 production in HGFs (NG, U0126: $\mathrm{P}<0.0001 ; 10 \mu \mathrm{M}$ Bay: $\mathrm{P}=0.005 ; \mathrm{HG}, \mathrm{U} 0126: \mathrm{P}<0.0001 ; 10 \mu \mathrm{M}$ Bay: $\mathrm{P}=0.75 ; 25$ $\mu \mathrm{M}$ Bay: $\mathrm{P}<0.0001$, ANOVA Tukey-HSD). Flutamide also had no effects on the IL-6/sIL-6Rinduced MMP-1 production in HGFs (NG: $\mathrm{P}=0.99$; HG: $\mathrm{P}=0.99$, ANOVA Tukey-HSD). Finally, IL-1 $\beta$ and IL-6/sIL-6R induced phosphorylation of both p44/42 MAPK and I $\kappa \beta \alpha$ in HGFs cultured with $\mathrm{NG}$, and the increase of phosphorylation was dramatically enhanced in HGFs cultured with HG (Fig. 3D and 4D). There was no significant difference between NG and MN in induction levels of the each phosphorylation. 


\section{Cellular Physiology Cell Physiol Biochem 2018;50:973-986 and Biochemistry \begin{tabular}{l|l} 
DOl: 10.1159/000494481 & $\begin{array}{l}\text { O 2018 The Author(s). Published by S. Karger AG, Basel } \\
\text { www.karger.com/cpb }\end{array}$
\end{tabular}

Fig. 4. Effects of high glucose on IL-6+sIL6R-induced MMP-1 and TIMP-1 production in HGFs. Levels of (A) MMP-1, (B) TIMP-1 production in HGFs. After HGFs were cultured with $5.5 \mathrm{mM}$ glucose (NG) or $25 \mathrm{mM}$ glucose conditions, cells were treated with IL-6+sIL$6 \mathrm{R}$ (50 $\mathrm{ng} / \mathrm{ml}$ each) for $24 \mathrm{~h}$ and the culture supernatants were collected. As an osmotic control for $\mathrm{HG}$, the cells were cultured with NG conditions supplemented with $19.5 \mathrm{mM}$ mannitol (MN). (C) For inhibitor experiments, HGFs were pretreated with IKK inhibitor Bay11-7082 $(10,25,50 \mu \mathrm{M})$ for $8 \mathrm{~h}$, ERK inhibitor U0126 $(10 \mu \mathrm{M})$, or androgen receptor inhibitor flutamide $(10 \mu \mathrm{M})$ for $3 \mathrm{~h}$ and treated with IL-1 $\beta$ for $24 \mathrm{~h}$. MMP-1 and TIMP-1 levels were measured using ELISA methods. Data represents as the mean \pm SD from 3 independent experiments. (D) Enhancement of IL-6+sIL-6R-induced signaling in HGFs cultured with HG conditions. Cell lysates were resolved by SDS-PAGE and analyzed using Western blotting probed with antibodies against phospho-p44/42 MAPK and phosphoI $\mathrm{B} \alpha$. Equal loading of total lysates $(10 \mu \mathrm{g})$ was confirmed by re-probing with antibodies against $\beta$-actin. NS, not significant differences.

*, $\mathrm{P}<0.05$; **, $\mathrm{P}<0.01$, as compared with control (ANOVA Tukey-HSD).

Fig. 5. Induction of MMP-1 and VEGF by costimulation of IL-1 $\beta$ and sIL-6R in HGFs. (A) IL$1 \beta$-induced IL- 6 production in HGFs in a dose dependent manner. After HGFs were cultured with $5.5 \mathrm{mM}$ glucose (NG) condition, cells were treated with IL-1 $\beta$ for $24 \mathrm{~h}$ and the culture supernatants were collected. IL-6 levels were measured using ELISA methods. (B) Effects of high glucose (HG) on IL-1 $\beta$-induced IL- 6 production in HGFs. After HGFs were cultured with NG or HG conditions, cells were treated with IL-1 $\beta$ ( $1 \mathrm{ng} / \mathrm{ml})$ for $24 \mathrm{~h}$ and the culture supernatants were collected. As an osmotic control for HG, cells were cultured in NG medium supplemented with $19.5 \mathrm{mM}$ mannitol (MN). Levels of (C) MMP-1, (D) VEGF production in HGFs. After HGFs were cultured

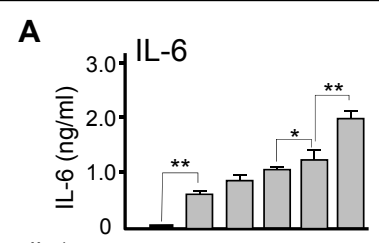

IL-1 $\beta$ (ng/ml): $00.050 .10 .51 \quad 5$

C

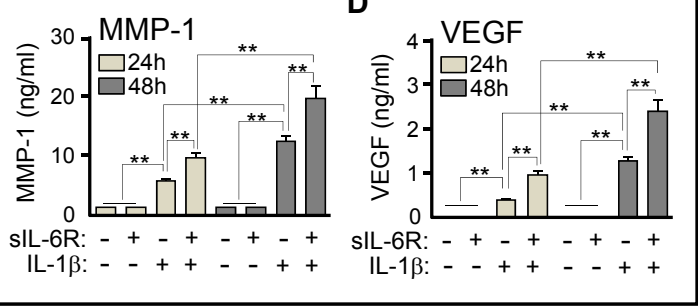

with $5.5 \mathrm{mM}$ glucose $(\mathrm{NG})$ condition, cells were treated with combination of IL-1 1 ( $1 \mathrm{ng} / \mathrm{ml})$ and sIL-6R (50 $\mathrm{ng} / \mathrm{ml}$ ) in HGFs for $24 \mathrm{~h}$ and the culture supernatants were collected. Data represents as the mean \pm SD from 3 independent experiments. NS, not significant differences. ${ }^{*}, \mathrm{P}<0.05$; ${ }^{* *}, \mathrm{P}<0.01$, as compared with control (ANOVA Tukey-HSD). 


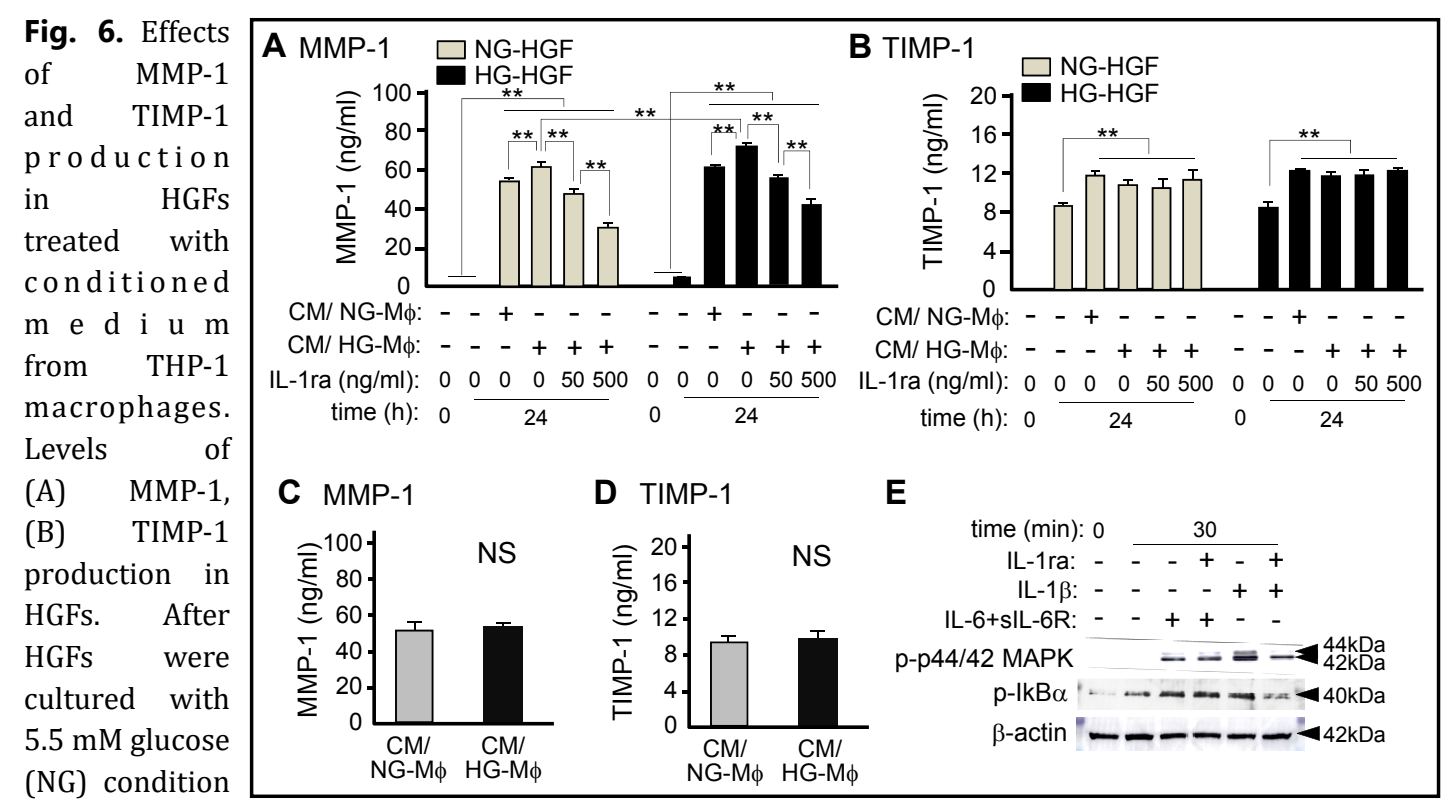

or $25 \mathrm{mM}$

glucose (HG), cells were treated with conditioned medium (CM) from THP-1 macrophages cultured with NG or HG conditions and the culture supernatants were collected. MMP-1 and TIMP-1 levels were measured using ELISA methods. To examine the effects of IL-1 $\beta$ containing in CM, HGFs were pre-treated with IL-1ra (50, $500 \mathrm{ng} / \mathrm{ml})$. Levels of (C) MMP-1, (D) TIMP-1 contained in CM from THP-1 macrophages cultured with NG or HG conditions. Data represents as the mean \pm SD from 3 independent experiments. (E) Inhibitory effects of IL-1ra (500 ng/ml) on the IL-1 $\beta$ signaling in HGFs. Cell lysates were resolved by SDS-PAGE and analyzed using Western blotting probed with antibodies against phospho-p44/42 MAPK and phospho$\mathrm{I} \kappa \mathrm{B} \alpha$. Equal loading of total lysates $(10 \mu \mathrm{g})$ was confirmed by re-probing with antibodies against $\beta$-actin. NS, not significant differences. *, $\mathrm{P}<0.05$; **, $\mathrm{P}<0.01$, as compared with control (ANOVA Tukey-HSD).

Indirect effects of IL-1 $\beta$ on IL-6 signaling-induced MMP-1 and VEGF production in HGFS

IL-1 $\beta$ increased significantly IL-6 production in HGFs in a dose dependent manner ( $\mathrm{P}=0.019,0.5$ vs $1 \mathrm{ng} / \mathrm{ml} \mathrm{IL-1 \beta ;} \mathrm{P}<0.0001,1$ vs $5 \mathrm{ng} / \mathrm{ml} \mathrm{IL-1 \beta}$, ANOVA Tukey-HSD) (Fig. 5A). There were no significant differences between NG and HG in $1 \mathrm{ng} / \mathrm{ml}$ of IL-1 $\beta$-induced IL- 6 production in HGFs (Fig. 5B). IL-1 $\beta$ increased MMP- 1 and VEGF production in HGFs, and sIL6R did not induce the MMP-1 and VEGF production (Fig. 5C and 5D). IL-1 $\beta$-induced increase of MMP-1 and VEGF in HGFs was enhanced significantly by sIL-6R (MMP-1: 24h, $\mathrm{P}=0.0002$; 48h, $\mathrm{P}<0.0001$; VEGF: 24, 48h, $\mathrm{P}<0.0001$, IL-1 $\beta+$ sIL-6R vs. IL-1 $\beta$, ANOVA Tukey-HSD).

\section{Effects of CM from THP-1 macrophages on MMP-1 production in HGFs cultured with NG or} HG conditions

In HGFs cultured with NG, CM from THP-1 macrophages cultured with NG increased significantly MMP-1 production compared with untreated cells $(\mathrm{P}<0.0001$, ANOVA TukeyHSD) (Fig. 6A). CM from THP-1 macrophages cultured with HG increased significantly the MMP-1 production compared with those of CM from THP-1 macrophages cultured with NG $(\mathrm{P}=0.0026$, ANOVA Tukey-HSD). Induction of MMP-1 by the CM from THP-1 macrophages cultured with HG was significantly inhibited by dose dependent of IL-1ra $(\mathrm{P}<0.0001,0$ vs. $50 \mathrm{ng} / \mathrm{mL}$ IL-1ra; $\mathrm{P}<0.0001,50$ vs. $500 \mathrm{ng} / \mathrm{mL}$ IL-1ra, ANOVA Tukey-HSD). Next, in HGFs cultured with HG, the similar responses were observed compared with those of HGFs cultured with NG. CM from THP-1 macrophages cultured with HG increased significantly the MMP-1 production in HGFs cultured with HG compared with those of HGFs cultured with NG (P<0.0001, ANOVA Tukey-HSD). The induction of MMP-1 by the CM from THP-1 macrophages cultured with HG was significantly inhibited by dose dependent of IL-1ra in HGFs cultured with HG $(\mathrm{P}<0.0001,0$ vs. $50 \mathrm{ng} / \mathrm{mL}$ IL-1ra; $\mathrm{P}=0.0001,50$ vs. $500 \mathrm{ng} / \mathrm{mL}$ IL- 


\section{Cellular Physiology Cell Physiol Biochem 2018;50:973-986 \begin{tabular}{ll|l} 
and Biochemistry Published onlıne: 23 October 2018 & $\begin{array}{l}\text { (c) } 2018 \text { The Author(s). Published by S. Karger AG, Basel } \\
\text { www.karger.com/cpb }\end{array}$ \\
\hline
\end{tabular} \\ Lew et al.: High Glucose Induces Severe Periodontitis.}

1ra, ANOVA Tukey-HSD). No significant increase of MMP-1 was observed in the CM from THP-1 macrophages cultured with both NG and HG ( $\mathrm{P}=0.23$, Student's $t$-test) (Fig. 6C).

There were no significant differences between $\mathrm{CM}$ from macrophages cultured with NG and HG in TIMP-1 production of HGFs (Fig. 6B). IL-1ra had no effects on the TIMP-1 production in HGFs. Whereas, both CM increased significantly the TIMP-1 production in HGFs cultured with both NG and HG $(\mathrm{P}<0.0001$, ANOVA Tukey-HSD). No significant increase of TIMP-1 was observed in the CM from THP-1 macrophages cultured with both NG and HG $(\mathrm{P}=0.46$, Student's $t$-test) (Fig. 6D).

IL-1 $\beta$ and IL-6/sIL-6R induced the phosphorylation of both p44/42 MAPK and IкB $\alpha$ in HGFs cultured with NG, and the increase of phosphorylation of both p44/42 MAPK and I $\mathrm{B} \alpha$ by IL-1 $\beta$, but not IL-6/sIL-6R were dramatically inhibited in HGFs pre-treated with IL-1ra.

\section{Discussion}

Periodontitis is a multifactorial inflammatory disease that causes tooth loss [18], and poor glycemic control has often been associated with severity of periodontitis clinically [3]. In our clinical study, significant progression of periodontitis was also observed in diabetic patients compared with non-diabetic patients (Table 1). Inversely, to examine whether glycemic conditions in patients with severe periodontitis are poor compared with patients with non-severe periodontitis, we performed another cross-sectional analysis (see supplemental Table). Interestingly, blood HbA1c levels in periodontitis patients with 6 mm over PPD (severe periodontitis) were higher statistically than in periodontitis patients without $6 \mathrm{~mm}$ over PPD (non-severe periodontitis). These bidirectional results indicate the clinical appropriateness of our database.

At first, we examined whether there were positive relationship between diabetic conditions and GCF IL-1 $\beta$ levels in inflamed periodontal lesions. As shown in Table 1, there was no statistical difference between non-diabetic patients and diabetic patients in GCF IL$1 \beta$ levels, although the tendency was observed $(\mathrm{P}=0.083)$. Whereas, GCF IL- $1 \beta$ levels were statistically correlated to blood HbA1c levels of the diabetic patients (Table 2). Although there was no statistical difference between non-diabetic patients and diabetic patients in GCF sIL-6R levels ( $\mathrm{P}=0.36)$, importantly, GCF sIL-6R levels were also statistically correlated to blood HbA1c levels of diabetic patients (Table 2). These clinical findings indicate diabetic conditions such as increased glycated albumin may induce IL-1 $\beta$ and sIL-6R production in inflamed periodontal tissues.

IL-1 $\beta$ and IL- 6 are important pro-inflammatory cytokines in the progression of chronic inflammatory disease [19]. As shown in Fig. 1A, we demonstrated that CPT did not induce IL-6 production in THP-1 macrophages, although Pg LPS induced the IL-6 production significantly. We have considered that Pg infection has an important role in the early stages of periodontitis with or without $\mathrm{DM}$, because the periodontitis is a bacterial infectious disease. Interestingly, we found for the first time that $\mathrm{HG}$ increased IL-1 $\beta$ production significantly in THP-1 macrophages, and the increase of IL- $1 \beta$ was more enhanced by CPT (Fig. $2 \mathrm{~B}$ ). IL-1 $\beta$ also induced dramatically IL-6 production in HGFs (Fig. 5A). Furthermore, we showed previously that IL-6 binding to HGFs increases significantly in the presence of sIL-6R [20]. Considering the possible source of sIL-6R in periodontitis lesions, we reported that sIL-6R production was induced by IL- 6 and CPT in THP-1 macrophages [7, 21]. Importantly, we showed that CPT-mediated induction of sIL-6R inhibited significantly in THP-1 macrophages by TACE specific inhibitor, TAPI-1 (Fig. 1B). In addition, we demonstrated that HG also increased sIL-6R production significantly in THP-1 macrophages in a dose dependent manner via TACE activation (Fig. 2E). Franchimont et al. reported previously that IL-1/TNF-mediated induction of IL-6R shedding in osteoblastic cells is at least partly dependent on TACE activation [22]. Furthermore, Jones SA et al. reported that shedding of IL-6R was activated by the $\mathrm{Ca}^{2+}$ ionophore, ionomycin, and inhibited by the TAPI in THP-1 macrophages [23]. Although the effects of glucose on the $\mathrm{Ca}^{2+}$ mobilization are unclear, their findings encourage 


\section{Cellular Physiology Cell Physiol Biochem 2018;50:973-986 \begin{tabular}{ll|l} 
and Biochemistry Published online: 23 October 2018 & $\begin{array}{l}\text { (c) } 2018 \text { The Author(s). Published by S. Karger AG, Basel } \\
\text { www.karger.com/cpb }\end{array}$ \\
\hline
\end{tabular} \\ Lew et al.: High Glucose Induces Severe Periodontitis.}

our results. Because TACE levels in GCF are higher in periodontitis patients than in healthy subjects [24], sIL-6R induction by TACE may have an important role in the pathogenesis of periodontitis. A series of results suggest that shedding of IL-6R on cell surface may be induced by CPT and HG-mediated TACE activation in THP-1 macrophages.

MMP-1 plays a key role in the destruction of gingival collagen fibers because type I collagen is dominant in gingival connective tissue [25]. In addition, TIMPs are considered to be important molecules to regulate the actions of MMPs [25], and a disturbed balance of MMPs and TIMPs should be involved in the progression of periodontitis [26]. IL-1 $\beta$ and IL-6 may be responsible to the tissue destruction by increasing MMPs from HGFs [21]. In view of severe periodontitis in diabetic patients, therefore, we examined the effects of HG on IL-1 $\beta$ or IL-6-induced MMP-1 and TIMP-1 in HGFs. As shown in Fig. 3 and 4, HG enhanced significantly IL-1 $\beta$ or IL-6/sIL-6R-induced MMP-1 production via MAPKs and NF- $\kappa B$ pathway in HGFs. $\mathrm{NF}-\kappa \mathrm{B}$ pathway is activated by various cellular kinases including MAPKs, which are a group of signaling molecules mainly consisting of three well-characterized subfamilies: ERK1/2, JNK and p38 MAPK [27]. Our previous finding showed that HG enhances dramatically the gp130-mediated ERK pathway in IL-6/sIL-6R-treated HGFs [14]. We demonstrated that phosphorylation of IKB $\alpha$ was also significantly enhanced by IL-1 $\beta$ and IL-6/sIL-6R in HGFs cultured with $\mathrm{HG}$ condition. Although the enhancement of NF- $\kappa \mathrm{B}$ pathway may be induced followed by ERK activation, further experiments will be needed using siRNA techniques to understand the distinct signaling pathway. IL- $1 \beta$ decreased significantly TIMP- 1 production in HGFs, whereas IL-6/sIL-6R had no effects on TIMP-1 production in HGFs. These results suggest that the influence of MMP-1 should be enhanced dramatically in inflamed periodontal tissues of diabetic patients. HG-mediated increase of MMP- 1 by IL- $1 \beta$ or IL-6/ sIL-6R in HGFs would have an important role in the pathophysiology of severe periodontitis with DM. Recent studies reported that the MMP-1/TIMP-1 ratio in inflamed gingival tissues increased in periodontitis patients with uncontrolled glycemic conditions [28]. These clinical findings support our in vitro findings. Additionally, HG also increased significantly MMP-1 production in HGFs. We considered that HG affects to the cell responses by a combination of two reasons: 1 . elevated glucose availability, 2. osmotic effects. We notice the significant production of MMP-1 may be, at least in part, related to the osmotic effects of HG, because the same concentration of mannitol also increased significantly the MMP-1 production even in un-treated HGFs as shown in Fig. 4A.

Next, we focused on the potential of IL- $1 \beta$ in periodontitis lesions. Importantly, IL-1 $\beta$ dramatically increased IL-6 production in HGFs (Fig. 5A). Whereas HG had no effects on the IL-1 $\beta$-induced IL-6 production in HGFs. (Fig. 5B). Therefore, IL- 6 cascades induced by IL$1 \beta$ surrounding HGFs may be equivalent efficacy in pathogenesis of periodontitis whether the patients with DM or not. Interestingly, both MMP-1 and VEGF production were induced significantly and synergistically in HGFs co-stimulated by IL-1 $\beta$ and sIL-6R, even though without IL-6 (Fig. 5B and 5C). These findings suggest that sIL-6R has an important role in the induction of MMP-1 and VEGF in HGFs secondarily in response to IL- 6 produced by IL-1 $\beta$. IL-1 $\beta$ induces both direct signals of IL- $1 \beta$ and indirect signals of IL-6, if sIL-6R was produced by immune/inflammatory cells such as macrophages surrounding HGFs.

Finally, we examined the possibility of HGFs-macrophages crosstalk in inflamed periodontal tissues of diabetic patients. As shown in Fig. 6A, in HGFs cultured with NG, CM from THP-1 macrophages cultured with HG increased significantly MMP-1 production compared with those of NG. Furthermore, the increase of MMP-1 was enhanced significantly in HGFs cultured with HG, and the culture conditions simulate the conditions of periodontitis with DM. Since protein factors contained in CM are various and unclear, exactly, the precise mechanism of MMP-1 induction remains unknown in this culture system. However, IL$1 \mathrm{ra}$, known as IL-1 $\beta$ antagonist, suppressed the MMP-1 production in HGFs. Therefore, we considered that the induction of MMP-1 by CM from THP-1 macrophages cultured with HG, at least in part, depends on IL-1 $\beta$ effects. Since rheumatoid arthritis patients have a high 


\section{Cellular Physiology Cell Physiol Biochem 2018;50:973-986 and Biochemistry \begin{tabular}{l|l} 
DOl: 10.1159/000494481 & $\begin{array}{l}\text { O } 2018 \text { The Author(s). Published by S. Karger AG, Basel } \\
\text { www.karger.com/cpb }\end{array}$
\end{tabular}

Fig. 7. Schematic representation of HG-mediated HGFs and macrophages crosstalk: A possible mechanism of severe periodontitis with diabetes. In inflamed periodontal tissues of diabetic patients, calprotectin produced by neutrophils induces sIL-6R production in macrophages. HG induces IL-1 $\beta$ and sIL-6R production in macrophages. In the pathogenesis of periodontitis, macrophages may be one of the key cells, because Pg LPS also induces IL-6 production. IL-1 $\beta$ and sIL-6R induce MMP-1 production synergistically in HGFs,

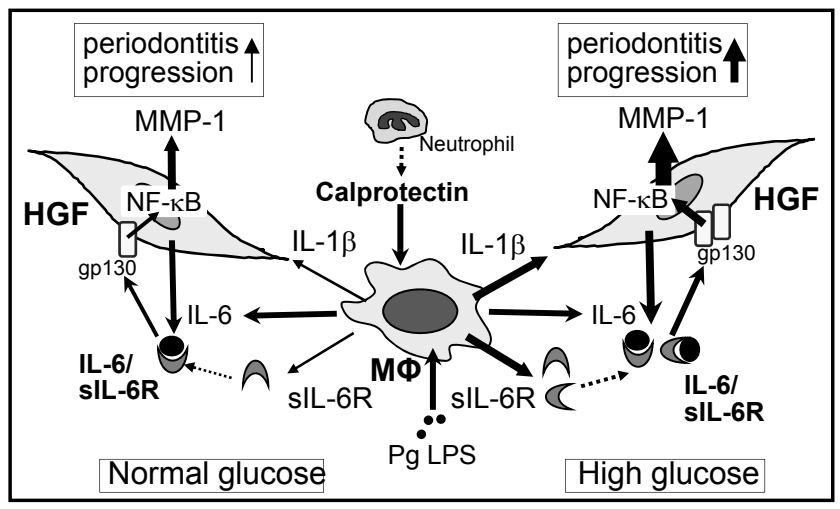
because IL-1 $\beta$ induces dramatically IL- 6 production in HGFs. Taken together, both direct effects of IL-1 $\beta$ on responsiveness of HGFs and indirect effects of IL- $1 \beta$ via activation of IL- 6 signaling of HGFs by inducing sIL6R from macrophages infiltrated in periodontitis lesion may exacerbate the pathogenesis of periodontitis synergistically in diabetic patients.

level of IL-1, clinically, the blockade of IL-1 receptors by external IL-1ra such as Anakinra modifies the disease progression [29]. IL-1ra may be a hopeful candidate for therapeutic strategy for preventing and treating in severe periodontitis with DM.

AGEs play an important role in the pathogenesis of diabetic complications. Skin AF, a marker of AGE accumulation in tissues, can be measured noninvasively using a skin AF reader [30]. Meerwaldt reported that skin AF increased statistically in diabetic patients [31]. Furthermore, Yu showed that AGEs upregulate the expression of MMP-1 in HGFs [32]. Similar to the reports, we showed that AGEs induces IL-6 production in HGFs [33]. On the other hand, our cross-sectional study showed that no statistical difference was observed between non-diabetic patients and diabetic patients in the skin AF (Table 1). We are not surprising because diabetic/glycemic conditions in the majority of patients have been well-controlled medically in the population of this study. Statistical differences should be observed between non-diabetic patients and diabetic patients in the skin AF by re-analysis using other population including patients with severe/poor diabetic conditions.

In the clinical study, although we have proposed the relationships of several glycemic factors to the GCF IL-1 $\beta$ and sIL-6R levels, we are only able to show associations and not causality because this was a cross-sectional analysis. However, a series of findings by both clinical and in vitro study suggest that diabetic conditions such as HG may induce IL-1 $\beta$ and sIL-6R production from macrophages in inflammatory periodontal tissues and may exacerbate the periodontitis synergistically via MMP-1 production from HGFs (Fig. 7). Enhancement of CPT or HG-induced IL-1 $\beta$ and IL- 6 cascades in HGFs may play a key role in periodontitis progression through the crosstalk of fibroblasts-macrophages. This pathway could be an attractive target to clarify the pathophysiology of severe periodontitis with DM and contribute to establish the novel therapeutic concept in the disease.

\section{Acknowledgements}

We thank the staff of Department of Periodontics, Tokushima University Hospital for their clinical assistance in cross-sectional study.

JHL performed in vitro assay, statistical analysis and wrote the article. JHL, YK, YN and TI recruited patients. JK and TN participated in data interpretation. JHL, KN and TN planned the study design. KN supervised the analysis and revised the article. 


\section{Cellular Physiology Cell Physiol Biochem 2018;50:973-986 \begin{tabular}{l|l|l} 
DOl: 10.1159/000494481 & $\begin{array}{l}\text { O 2018 The Author(s). Published by S. Karger AG, Basel } \\
\text { www.karger.com/cpb }\end{array}$ \\
\hline
\end{tabular} \\ Lew et al.: High Glucose Induces Severe Periodontitis.}

This study was supported by Grant-in-Aid for Scientific Research (B) (No. 15H05054) and Scientific Research (C) (No. 16K11832) from the Japan Society for the Promotion of Science.

The study protocol was approved by the local ethics committee of Tokushima University Hospital (No. 2325).

\section{Disclosure Statement}

There is no conflict of interests regarding the publication of this paper.

\section{References}

-1 Porta M, Bandello F: Diabetic retinopathy A clinical update. Diabetologia 2002;45:1617-1634.

- Nishimura F, Takahashi K, Kurihara M, Takashiba S, Murayama Y: Periodontal disease as a complication of diabetes mellitus. Ann Periodontol 1998;3:20-29.

3 Teshome A, Yitayeh A: The effect of periodontal therapy on glycemic control and fasting plasma glucose level in type 2 diabetic patients: systematic review and meta-analysis. BMC Oral Health 2016;17:31.

-4 Kwan Tat S, Padrines M, Théoleyre S, Heymann D and Fortun Y: IL-6, RANKL, TNF-alpha/IL-1: interrelations in bone resorption pathophysiology. Cytokine Growth Factor Rev 2004;15:49-60.

5 Okada H, Murakami S. Cytokine expression in periodontal health and disease. Crit Rev Oral Biol Med 1998;9:248-266.

6 Rose-John S: The Soluble Interleukin 6 Receptor: Advanced Therapeutic Options in Inflammation. Clin Pharmacol Ther 2017;102:591-598.

-7 Kajiura Y, Lew JH, Ikuta T, Nishikawa Y, Kido JI, Nagata T, Naruishi K: Clinical significance of GCF sIL-6R and calprotectin to evaluate the periodontal inflammation. Ann Clin Biochem 2017;54:664-670.

-8 Andriankaja OM, Barros SP, Moss K, Panagakos FS, DeVizio W, Beck J, Offenbacher S: Levels of serum interleukin (IL)-6 and gingival crevicular fluid of IL-1beta and prostaglandin E2 among non-smoking subjects with gingivitis and type 2 diabetes. J Periodontol 2009;80:307-316.

-9 Duarte PM, Bezerra JP, Miranda TS, Feres M, Chambrone L, Shaddox LM: Local levels of inflammatory mediators in uncontrolled type 2 diabetic subjects with chronic periodontitis. J Clin Periodontol 2014;41:11-18.

10 Birkedal-Hansen H: Role of matrix metalloproteinases in human periodontal diseases. J Periodontol 1993;64:474-484.

11 Naruishi K, Takashiba S, Nishimura F, Chou HH, Arai H, Yamada H, Murayama Y: Impairment of gingival fibroblast adherence by IL-6/sIL-6R. J Dent Res 2001;80:1421-1424.

12 Nishikawa Y, Kajiura Y, Lew JH, Kido JI, Nagata T, Naruishi K: Calprotectin Induces IL-6 and MCP-1 Production via Toll-Like Receptor 4 Signaling in Human Gingival Fibroblasts. J Cell Physiol 2017;232:18621871.

13 Capitão M, Soares R: Angiogenesis and inflammation crosstalk in diabetic retinopathy. J Cell Biochem 2016;117:2443-2453.

14 Omori K, Naruishi K, Nishimura F, Yamada-Naruishi H, Takashiba S: High glucose enhances interleukin6-induced vascular endothelial growth factor 165 expression via activation of gp130-mediated p44/42 MAPK-CCAAT/enhancer binding protein signaling in gingival fibroblasts. J Biol Chem 2004;279:6643-6649.

-15 Wassenaar A, Verschoor T, Kievits F, Den Hartog MT, Kapsenberg ML, Everts V, Snijders A: CD40 engagement modulates the production of matrix metalloproteinases by gingival fibroblasts. Clin Exp Immunol 1999;115:161-167.

16 Domeij H, Modéer T, Yucel-Lindberg T: Matrix metalloproteinase-1 and tissue inhibitor of metalloproteinase-1 production in human gingival fibroblasts: the role of protein kinase C. J Periodontal Res 2004;39:308-314.

17 Armitage GC: Development of a classification system for periodontal diseases and conditions. Ann Periodontol 1999;4:1-6. 


\section{Cellular Physiology Cell Physiol Biochem 2018;50:973-986 \begin{tabular}{l|l|l} 
DOl: 10.1159/000494481 & $\begin{array}{l}\text { O 2018 The Author(s). Published by S. Karger AG, Basel } \\
\text { www.karger.com/cpb }\end{array}$ \\
\hline
\end{tabular}}

Lew et al.: High Glucose Induces Severe Periodontitis.

18 Hassell TM: Tissues and cells of the periodontium. Periodontol 2000 1993;3:9-38.

19 Barksby HE, Lea SR, Preshaw PM, Taylor JJ: The expanding family of interleukin-1 cytokines and their role in destructive inflammatory disorders. Clin Exp Immunol 2007;149:217-225.

-20 Naruishi K, Takashiba S, Chou HH, Arai H, Nishimura F, Murayama Y: Role of soluble interleukin-6 receptor in inflamed gingiva for binding of interleukin-6 to gingival fibroblasts. J Periodontal Res 1999;34:296-300.

-21 Sawada S, Chosa N, Ishisaki A, Naruishi K: Enhancement of gingival inflammation induced by synergism of IL-1 $\beta$ and IL-6. Biomed Res 2013;34:31-40.

-22 Franchimont N, Lambert C, Huynen P, Ribbens C, Relic B, Chariot A, Bours V, Piette J, Merville MP, Malaise M: Interleukin-6 receptor shedding is enhanced by interleukin-1beta and tumor necrosis factor alpha and is partially mediated by tumor necrosis factor alpha-converting enzyme in osteoblast-like cells. Arthritis Rheum 2005;52:84-93.

23 Jones SA, Horiuchi S, Novick D, Yamamoto N, Fuller GM: Shedding of the soluble IL-6 receptor is triggered by $\mathrm{Ca}^{2+}$ mobilization, while basal release is predominantly the product of differential mRNA splicing in THP-1 cells. Eur J Immunol 1998;28:3514-3522.

-24 Bostanci N, Emingil G, Afacan B, Han B, Ilgenli T, Atilla G, Hughes FJ, Belibasakis GN: Tumor necrosis factoralpha-converting enzyme (TACE) levels in periodontal diseases. J Dent Res 2008;87:273-277.

25 Reynolds JJ: Collagenases and tissue inhibitors of metalloproteinases: a functional balance in tissue degradation. Oral Dis 1996;2:70-76.

26 Verstappen J, Von den Hoff JW: Tissue inhibitors of metalloproteinases (TIMPs): their biological functions and involvement in oral disease. J Dent Res 2006;85:1074-1084.

27 Lopez S, Gomez E, Torres MJ, Pozo D, Fernandez TD, Ariza A, Sanz ML, Blanca M, Mayorga C: Betalactam antibiotics affect human dendritic cells maturation through MAPK/NF- $\kappa$ B systems. Role in allergic reactions to drugs. Toxicol Appl Pharmacol 2015;288:289-99

28 Bastos MF, Tucci MA, de Siqueira A, de Faveri M, Figueiredo LC, Vallim PC, Duarte PM: Diabetes may affect the expression of matrix metalloproteinases and their inhibitors more than smoking in chronic periodontitis. J Periodontal Res 2017;52:292-299.

29 Nikfar S, Saiyarsarai P, Tigabu BM, Abdollahi M: Efficacy and safety of interleukin-1 antagonists in rheumatoid arthritis: a systematic review and meta-analysis. Rheumatol Int 2018;38:1363-1383.

-30 Temma J, Matsuhisa M, Horie T, Kuroda A, Mori H, Tamaki M, Endo I, Aihara K, Abe M, Matsumoto T: Noninvasive Measurement of Skin Autofluorescence as a Beneficial Surrogate Marker for Atherosclerosis in Patients with Type 2 Diabetes. J Med Invest 2015;62:126-129.

-31 Meerwaldt R, Graaff R, Oomen PHN, Links TP, Jager JJ, Alderson NL, Thorpe SR, Baynes JW, Gans ROB, Smit AJ: Simple non-invasive assessment of advanced glycation endproduct accumulation. Diabetologia 2004;47:1324-1330.

-32 Yu S, Li H, Ma Y, Fu Y: Matrix metalloproteinase-1 of gingival fibroblasts influenced by advanced glycation end products (AGEs) and their association with receptor for AGEs and nuclear factor- $\kappa \mathrm{B}$ in gingival connective tissue. J Periodontol 2012;83:119-126.

-33 Nonaka K, Kajiura Y, Bando M, Sakamoto E, Inagaki Y, Lew JH, Ikuta T, Yoshida K, Kobayashi T, Yoshie H, Nagata T, Kido J: Advanced glycation end-products increase IL-6 and ICAM-1 expression via RAGE, MAPK and NF-кB pathways in human gingival fibroblasts. J Periodontal Res 2018;53:334-344. 